\title{
Laparoscopic versus open cholecystectomy: complications and cost.
}

Colecistectomia laparoscópica versus aberta: complicações e custos

Aldo Cunha Medeiros, MD, PhD; Irami Araújo-Filho, MD, PhD; Marília Daniela Ferreira Carvalho, MD; Vanessa de Fátima Lima de Paiva Medeiros, MS; Ítalo Medeiros Azevedo; Antônio Medeiros Dantas Filho, MD, PhD.

Research performed at University Hospital Onofre Lopes, Federal University of Rio Grande do Norte (UFRN), Brazil. Supported by a grant from CNPq, Brazil.

Conflict of interest: none

Correspondence address: Aldo Cunha Medeiros, Department of Surgery, Federal University of Rio Grande do Norte, at Ave. Nilo Peçanha 620, Natal, RN, Brazil, Email: odlacm@gmail.com

Submitted: 01 march 2013. Accepted, after review: 25 march 2013.

\begin{abstract}
Purpose: Laparoscopic cholecystectomy (LC) is currently the most widely used surgical procedure for the treatment of gallstones. The aim of the study was to analyze and compare the postoperative results of patients undergoing laparoscopic cholecystectomy or open cholecystectomy $(\mathrm{OC})$ with regard to complications, recovery time, hospital stay and cost. Method: This is a prospective study, which analyzed 1015 patients, 20-65 years old, diagnosed with gallstones undergoing LC or OC. We evaluated postoperative respiratory complications, surgical site infection, deep vein thrombosis, time to oral feeding and ambulation, use of antibiotics, duration of the postoperative period and the cost of surgery. Results: We analyzed $470(46 \%)$ patients undergoing LC and 545 $(54 \%)$ OC. Most patients were female $(68,4 \%)$. Patients' comorbidities were hypertension (15.8\%), diabetes mellitus (4.0\%) and asthma (1.18\%). LC resulted in lower prevalence of postoperative complications $(2.9 \%)$ than OC $(5.13 \%)$. Postoperative hospitalization for $18-24$ hours was found in $71.68 \%$ of LC patients and in $13.4 \%$ in OC. The financial cost per surgery was US\$ 495.00 in LC and US\$ 435.00 in OC. Conclusion: Laparoscopic cholecystectomy showed higher benefits for patients with lower prevalence of postoperative complications, feeding earlier, shorter mean hospital stay and equivalent cost compared with open cholecystectomy.
\end{abstract}

Keywords: Cholecystectomy. Laparotomy. Laparoscopy. Postoperative complications. Cost. 
Laparoscopic versus open cholecystectomy: complications and cost

Medeiros, $A C$, et al

\section{RESUMO}

Objetivo: A colecistectomia laparoscópica é atualmente o procedimento cirúrgico mais utilizado para o tratamento de litíase biliar. O objetivo do estudo foi analisar e comparar o pós-operatório imediato de grupos de pacientes submetidos a colecistectomia laparoscópica ou colecistectomia aberta no que diz respeito a complicações, tempo de recuperação, tempo de internação e custo das operações. Método: Estudo prospectivo, no qual foram analisados 1015 pacientes, entre 20 e 65 anos, com diagnóstico de litíase biliar submetidos a colecistectomia laparoscópica ou aberta. Para avaliação do pós-operatório imediato foram avaliadas as complicações respiratórias, infecção do sítio cirúrgico, trombose venosa profunda, tempo para início da alimentação oral e deambulação, o uso de antibióticos, duração do período pósoperatório e o custo do tratamento cirúrgico Resultados. Foram analisados 470 (46\%) pacientes submetidos a colecistectomia laparoscópica e $545(54 \%)$, por via aberta. A maioria dos pacientes era do sexo feminino $(68,4 \%)$. As comorbidades apresentadas pelos pacientes foram hipertensão arterial $(15,8 \%)$, diabetes mellitus $(4,0 \%)$ e asma brônquica $(1,18 \%)$. A colecistectomia laparoscópica resultou em menor prevalência de complicações operatórias $(2,9 \%)$, maior número de pacientes com tempo de hospitalização pós-operatória abaixo de 18 horas $(71,68 \%)$ e um custo financeiro de $R \$$ 990,00 por procedimento cirúrgico. Comparada com a cirurgia aberta, os valores de complicações, tempo de hospitalização e custo foram respectivamente, 5,13\%, 13,4\% e $\mathrm{R} \$$ 870,00. Conclusão: A colecistectomia laparoscópica apresentou maiores benefícios aos pacientes, com menor prevalência de complicação pós-operatórias, alimentação mais precoce e menor tempo médio de internação e custo equivalente, quando comparada com a colecistectomia aberta.

Descritores: Colecistectomia. Laparotomia. Laparoscopia. Pós-operatório. Complicações. Custo.

\section{INTRODUCTION}

Laparoscopic cholecystectomy has become the treatment of choice for chronic cholecystitis around the world. Laparoscopic cholecystectomy is still reported as having a higher complication rate for acute cholecystitis than for chronic cholecystitis, with a currently reported postoperative complication rate of about $9 \%$ to $17 \%$ in some published series ${ }^{1}$.The broad range of the complication and conversion rates should be kept in mind because they depend on variables such as patient age, emergency intervention, ASA classification, and the presence of acute inflammation (gangrene, empyema, or perforation) of the gallbladder ${ }^{2}$. Since the introduction of laparoscopic 
cholecystectomy, many attempts have been made to identify risk factors that influence perioperative complications and conversion rates. For patients with a high probability of undergoing a complication, management can be optimized in the early preoperative decision-making process and during the surgical intervention to lower the risk of perioperative complications ${ }^{3}$.

In the early stage of laparoscopic cholecystectomy, it was considered unsafe or technically difficult to perform laparoscopic cholecystectomy for acute cholecystitis ${ }^{4,5}$. With increasing experience in laparoscopic surgery, many surgical services have reported on the use of laparoscopic cholecystectomy for acute cholecystitis, suggesting that it is technically feasible but at the expense of a high conversion rate ${ }^{6,7}$. and common bile duct lesions ${ }^{8}$. Routine use of the open procedure might enable more patients to have the operations during the acute phase because most surgeons are practiced in this approach. The impact of hospital stay and morbidity must also be taken into account. There is the expectation that open operation is associated with more pain and longer hospital stay ${ }^{9,10}$. In some trials successful laparoscopic cholecystectomy is associated with an earlier recovery and shorter hospital stay when compared with open cholecystectomy ${ }^{11}$. Other studies did not confirm these results and the potential advantages of early laparoscopic cholecystectomy can be offset by a high conversion rate to open surgery ${ }^{6}$.

It has been established that laparoscopic cholecystectomy could be performed at a treatment cost that is equal to or slightly less than that of open cholecystectomy, and with substantial cost savings to the patient and society due to the reduced loss of time from work ${ }^{12}$. The cost of laparoscopic cholecystectomy and open cholecystectomy or minilaparotomy cholecystectomy has been compared in some randomized controlled trials with divergent results ${ }^{13,14}$.

The aim of this study was to analyze and compare the perioperative results of patients undergoing laparoscopic and open cholecystectomy concerning to complications, hospital stay and cost.

\section{METHODS}

All patients having cholecystectomy at the Hospital Universitário Onofre Lopes (HUOL), Natal, Brazil, from January 1995 to December 2010 were prospectively registered in the study. Most of the operations were performed by professors of surgery, but residents participated in surgery under supervision. Patients were eligible to participate in the trial comparing conventional open cholecystectomy and laparoscopic cholecystectomy according to exclusion and inclusion criteria. Approval of the Hospital Ethics Committee was obtained for the study, and it was performed according to the 
Resolution 196/96 from National Council of Health, Brazil. The patients signed the informed consent. Informations about costs for the hospital services included in the study protocol were based on the table prices from Brazilian Medical Association. The cost of each day of hospital care included medication costs, food, care and taxes. All the trocars and instruments used in the laparoscopic surgeries were reusable.

We analyzed 1015 patients, aged 20-65 years, diagnosed with gallstone disease randomly assigned to laparoscopic cholecystectomy or open cholecystectomy. Excluded were those with confirmed choledocholithiasis and underwent concomitant surgeries, pregnant women and patients with liver cirrhosis or malignant tumors. Demographic data such as age, sex, emergency or elective procedure, surgical risk (ASA score), duration of surgery, use of prophylactic heparin, intercurrent diseases and use of prophylactic antibiotics were computed. Respiratory complications (pneumonia, bronchopneumonia, pleural effusion, pulmonary embolism), surgical site infections urinary infections, deep vein thrombosis and other complications were recorded from the immediate postoperative period until the time of hospital discharge. We evaluated the time to oral feeding and ambulation, length of postoperative hospital stay and the clinical conditions at the time of discharge. Data were statistically analyzed using the chi-square test, considering the significant differences at $p<0.05$.

\section{RESULTS}

Of the 1015 patients, 470 (46\%) underwent laparoscopic surgery and 545 (54\%), open cholecystectomy, distributed by gender and age as shown in Table 1. We found a relationship of a man to two women.

Table 1 - Prevalence of age and sex.

\begin{tabular}{l|ccccc}
\hline $\begin{array}{c}\text { Type of } \\
\text { cholecystectomy }\end{array}$ & Age & Male & Female & M:F Ratio & Total \\
\hline Laparoscopic & $45 \pm 11.9$ & 145 & 325 & $1: 2.4$ & 470 \\
Open & $46,6 \pm 10.2$ & 175 & 370 & $1: 2.1$ & 545 \\
\hline Total & $46,2 \pm 10.6$ & 320 & 695 & $1: 2.2$ & 1015 \\
\hline
\end{tabular}

Most of the patients had co-morbidities such as hypertension, asthma and diabetes mellitus (Table 2). 
Laparoscopic versus open cholecystectomy: complications and cost

Medeiros, AC, et al

Table 2 - Intercurrent illness (co-morbidities)

\begin{tabular}{l|cc}
\hline \multicolumn{1}{c|}{ Diseases } & $\begin{array}{c}\text { Laparoscopic } \\
\text { Cholecystectomy }\end{array}$ & Open colecystectomy \\
\hline Hipertension & 78 & 83 \\
Diabetes & 18 & 22 \\
Asthma & 5 & 7 \\
Nontoxic goiter & 0 & 2 \\
Lung enfhysema & 1 & 2 \\
AlDS & 0 & 1 \\
\hline
\end{tabular}

There was no difference in median time to onset of postoperative oral feeding. It was earlier in laparoscopic cholecystectomy, where 458 (97.4\%) patients received oral diet introduced in the first 5-6 hours, while in open surgery, the oral intake was introduced in $446(81.8 \%)$ patients after 24 hours (Table 3).

Table 3 - Time for the beginning of postoperative oral feeding

\begin{tabular}{l|ccccc}
\hline \multicolumn{1}{c|}{ Surgery } & 5 a $6 h$ & $12 h$ & $24 h$ & $48 h$ & $72 h$ \\
\hline Laparoscopic Cholecystectomy & 458 & 10 & 2 & 0 & 0 \\
\hline Open cholecystectomy & 5 & 38 & 446 & 46 & 10 \\
\hline
\end{tabular}

Mean operative time in laparoscopic surgery was 30 to 60 minutes in most 272 patients (57.9\%). Open surgery lasting 30 to 60 minutes were performed in 119 patients $(21.8 \%)$, significantly less when compared with laparoscopic surgery. We performed 181 (38,5\%) laparoscopic cholecystectomy in the time interval 61-120 minutes, significantly less than $416(62 \%)$ open cholecystectomy in the same time interval (61-180 minutes). (Table 4).

Table 4 - Operative time (minutes)

\begin{tabular}{l|ccccc}
\hline \multicolumn{1}{c|}{ Operation } & 30 a 60 & 61 a 120 & 121 a 180 & $>180$ min & TOTAL \\
\hline $\begin{array}{l}\text { Laparoscopic } \\
\text { Cholecystectomy }\end{array}$ & 272 & 181 & 14 & 3 & 470 \\
\hline Open cholecystectomy & 119 & 338 & 78 & 10 & 545 \\
\hline p-value & \multicolumn{5}{c}{$\mathrm{p}<0,05$} \\
\hline
\end{tabular}

Operative complications resulting from laparoscopic procedure occurred in 14 $(2.9 \%)$ patients, 6 patients with wound infection. The remaining 8 patients who had complications were affected by pneumonia, subphrenic abscess, choleperitoneum, deep vein thrombosis, pulmonary embolism, liver hematoma associated with respiratory 
failure, subcutaneous emphysema and perforation of the diaphragm. Two deaths occurred in patients undergoing laparoscopic surgery, one for pulmonary embolism and another for liver damage. In patients undergoing open cholecystectomy postoperative complications occurred in $5.13 \%$ of cases. The surgical site infection was the most frequent complication, diagnosed in 13 patients, followed by urinary tract infection in 6 patients. There were no deaths in patients undergoing open cholecystectomy (Tables 5 and 6).

Table 5 - Postoperative complications observed in patients undergoing laparoscopic and open cholecystectomy.

\begin{tabular}{l|cc}
\hline \multicolumn{1}{c|}{ Complications } & $\begin{array}{c}\text { Laparoscopic } \\
\text { Cholecystectomy }\end{array}$ & Open Cholecystectomy \\
\hline Wound infection & 6 & 13 \\
Urinary infection & 0 & 6 \\
Subphrenic abcess & 1 & 2 \\
Bile duct injury & 1 & 2 \\
Pneumonia & 1 & 1 \\
Deep vein thrombosis & 1 & 1 \\
Pulmonary embolism & 1 & 0 \\
Hepatic hematoma & 1 & 0 \\
Respiratory infection & 0 & 2 \\
Pleural efusion & 0 & 1 \\
Diaphragm perforation & 1 & 0 \\
Subcutaneus enfisema & 1 & 0 \\
\hline \multicolumn{1}{c}{ TOTAL } & $14(2.9 \%)$ & $28(5.13 \%) \mathrm{p}<0.05$ \\
\hline
\end{tabular}

Table 6 - Operative mortality

\begin{tabular}{l|cc}
\hline \multicolumn{1}{c|}{ Operation } & Etiology & Mortality \\
\hline Laparoscopic Cholecystectomy & $\begin{array}{l}\text { Pulmonary embolism } \\
\text { Hepatic hematoma }+ \\
\text { respiratory failury }\end{array}$ & $\begin{array}{c}1 \text { patient } \\
1 \text { patient }\end{array}$ \\
\hline Open cholecystectomy & - & 0 \\
\hline
\end{tabular}

In patients undergoing laparoscopic surgery hospital stay was 18 to 24 hours in 436 patients $(92.7 \%)$, while open surgery resulted in a hospital stay of two to four days in 472 patients (86.6\%). 
Laparoscopic versus open cholecystectomy: complications and cost

Medeiros, $A C$, et al

Table 7 - Operations cost

\begin{tabular}{l|cccc}
\hline Cholecystectomy & Hospital day & Stay cost & Hospital cost & Total Cost (R\$) \\
\hline Laparoscopic & 458 & $36,640.00$ & $416,851.00$ & $453,491.00$ \\
\hline Open & 1221 & $97,680.00$ & $375,900.00$ & $473,580.00$ \\
\hline
\end{tabular}

The hospital stay of patients undergoing laparoscopic surgery resulted in 458 hospital stays, which corresponded to the total cost of $R \$ 36,640.00$. Open cholecystectomy patients resulted 1,221 hospital stays, contributing to a total daily cost of $R \$ 97,680.00$. The daily cost of hospitalization was $R \$ 80$.

When adding daily cost to hospital charges, laparoscopic cholecystectomy has contributed to a total cost of $R \$ 453,491.00$, equivalent to approximately $R \$ 990.15$ per procedure. Open cholecystectomy contributed to the total cost of $R \$ 473,580.00$, equivalent to $R \$ 868.95$ per surgery (Table 7 ). These data demonstrate that the laparoscopic technique had approximately the same cost to the hospital, compared to open cholecystectomy.

\section{DISCUSSION}

Laparoscopic cholecystectomy has largely supplanted the open technique. This is because of the numerous studies that have substantiated the benefits of laparoscopy, particularly its clinical advantages ${ }^{15-21}$. For those studies selected for their similarities to the method used in our own analysis, the mean postoperative stay for an open cholecystectomy has been 8 days compared with the 3 days recorded for laparoscopy ${ }^{22}$. In the present study, the duration of postoperative hospital stay for laparoscopic surgery was from 18 to 24 hs in 436 patients $(92,7 \%)$, and in open cholecystectomy was $2-4$ days in 472 patients $(86,6 \%)$. Trends in the duration of hospital stay for cholecystectomy have to be considered, indicating that for open cholecystectomy no further reduction in postoperative hospital stay could be future goal at our hospital.

The mean operating time for an open cholecystectomy has been given as 90 minutes, as opposed to 95 minutes for the laparoscopic procedure ${ }^{23}$. These data contrast with our results of 30 to 120 minutes and 130 to 180 minutes, respectively. Both perioperative and postoperative complications are thoroughly dealt with in most studies that have compared open and laparoscopic cholecystectomy ${ }^{24,25}$. Nevertheless, a comparison of complications based on groups of patients is not always apparent because of the differing exclusion criteria, periods of hospital stay, and definition of the term 'complication'. Usually, complications are classified as bile duct injury, vascular, transmural bowel injury, residual stones, wound or urinary tract infections, urinary retention, and ileus ${ }^{26}$. Bile duct injuries has been more common after laparoscopic than 
open cholecystectomy ${ }^{27}$. In the present study we had one case of bile duct injury. The patient was reoperated and the injury was successfully treated.

While there is general agreement as to the clinical benefits of laparoscopic over open cholecystectomy, the costs of both procedures are still a subject of controversy. Only few studies have placed their emphasis on comparing costs ${ }^{28}$. Some studies examined costs and has made use of a design that is generally similar to our study. The costs of an open cholecystectomy has ranged from US\$2,221 to US\$ 9,857, with a mean value of about US $\$ 4,953$. Our costs, roughly about US $\$ 435$, significantly below this mean. Similarly, the costs associated with laparoscopy at our Hospital was US\$ 495, meaning that the difference was not significant. We used reusable instruments. In a 1999 publication by Lefering et al. ${ }^{29}$, costs for a laparoscopic cholecystectomy using reusable instruments were a mean of US $\$ 1,699$. In an other study the authors ${ }^{30}$ calculated the costs of open procedures to be US\$ 3,611 and those for laparoscopy to be US\$3,034. Although a portion of the cost differences between studies can be attributed to non-standard national or regional features, the method used (inclusion and exclusion criteria, method of calculation of costs, etc.) has an important role. In particular, most hospital expenses can be assigned to individual patients only by means of a cost-sharing key. The selection of such criteria influences the total costs of cholecystectomy. However, irrespective of the criteria chosen, the predominant factor that differentiates the costs of the two procedures - in the present as well as in most other studies - is the duration of postoperative stay and the cost and deterioration of instruments and clips.

In conclusion, laparoscopic cholecystectomy offers the greatest benefits to patients, it was associated with a lower rate of postoperative complications, feeding earlier and shorter average hospital than open cholecystectomy. The costs of laparoscopic cholecystectomy was about the same as those of the open conventional procedure. The difference in cost was attributable to the considerably shorter postoperative stay after the laparoscopic procedure.

\section{REFERENCES}

1. Navez B, Mutter D, Russier $Y$, et al. Safety of laparoscopic approach for acute cholecystitis: retrospective study of 609 cases. World J Surg. 2001;25:1352-6.

2. Schäfer $M, K$ Kähenbühl $L$, Büchler $M W$. Predictive factors for the type of surgery in acute cholecystitis. Am J Surg. 2001;182: 291-7.

3. Kauvar DS, Braswell A, Brown BD, Harnisch M. Influence of resident and attending surgeon seniority on operative performance in laparoscopic cholecystectomy. J Surg Res. 2006; 132:159-63. 
4. Rai R, Sinha A, Rai S: Randomized clinical trial of open versus laparoscopic cholecystectomy in the treatment of acute cholecystitis. Br J Surg. 2005, 92:44-49. Br J Surg. 2005;92:494-9.

5. Nuzzo G, Giuliante F, Persiani R: The risk of biliary ductal injury during laparoscopic cholecystectomy. J Chir (Paris). 2004,141:343-53.

6. Johansson M, Thune A, Nelvin L, Stiernstam M, Westman B, Lundell L: Randomized clinical trial of open versus laparoscopic cholecystectomy in the treatment of acute cholecystitis. Br J Surg. 2005;92:44-9.

7. Asoglu O, Ozmen V, Karanlik H, Igci A, Kecer M, Parlak M, Unal ES: Does the complication rate increase in laparoscopic cholecystectomy for acute cholecystitis? $J$ Laparoendosc Adv Surg Tech. A 2004;14:81-6.

8. Johansson M, Thune A, Blomqvist A, Nelvin L, Lundell L: Management of acute cholecystitis in the laparoscopic era: results of a prospective, randomized clinical trial. J Gastrointest Surg. 2003;7:642-5.

9. Chau CH, Tang CN, Siu WT, Ha JP, Li MK: Laparoscopic cholecystectomy versus open cholecystectomy in elderly patients with acute cholecystitis: retrospective study. Hong Kong Med J. 2002;8:394-9.

10. Pessaux P, Regenet N, Tuech JJ, Rouge C, Bergamaschi R, Arnaud JP: a prospective comparative study in the elderly with acute cholecystitis. Surg Laparosc Endosc Percutan Tech. 2001;11:252-5.

11. Glavic Z, Begic L, Simlesa D, Rukavina A: Treatment of acute cholecystitis. A comparison of open vs laparoscopic cholecystectomy. Surg Endosc. 2001;15:398401.

12. Nilsson E, Ros A, Rahmqvist M, Bäckman K, Carlsson P. Cholecystectomy: costs and health-related quality of life: a comparison of two techniques. Int J Qual Health Care. 2004;16:473-82.

13. Calvert NW, Troy GP, Johnson AG. Laparoscopic cholecystectomy: a good buy? A cost comparison with small-incision (mini) cholecystectomy. Eur $J$ Surg. 2000;166:782-6.

14. McGinn FP, Miles AJG, Uglow $M$ et al. Randomized trial of laparoscopic cholecystectomy and mini-cholecystectomy. Br J Surg. 1995; 82:1374-7.

15. Rosenmüller MH, Thorén Örnberg M, Myrnäs $T$, Lundberg $O$, Nilsson E, Haapamäki MM. Expertise-based randomized clinical trial of laparoscopic versus small-incision open cholecystectomy. Br J Surg. 2013;100:886-94.

16. Trastulli S, Cirocchi R, Desiderio J, Guarino S, Santoro A, Parisi A, Noya G, Boselli C. Systematic review and meta-analysis of randomized clinical trials comparing single-incision versus conventional laparoscopic cholecystectomy. $\mathrm{Br} \mathrm{J}$ Surg. 2013;100:191-208. 
17. Van den Boezem PB, Kruyt PM, Cuesta MA, Sietses C. Single-incision versus conventional laparoscopic cholecystectomy: a case control study. Acta Chir Belg. 2012;112:374-7.

18. Fajardo R, Valenzuela JI, Olaya SC, Quintero G, Carrasquilla G, Pinzón CE, López C, Ramírez JC. [Cost-effectiveness of laparoscopic versus open cholecystectomy]. Biomedica. 2011;31:514-24.

19. Silveira FP, Nicoluzzi JE, Saucedo Júnior NS, Silveira F, Nicollelli GM, Maranhão BS. Evaluation of serum levels of interleukin-6 and interleukin-10 in patients undergoing laparoscopic versus conventional cholecystectomy. Rev Col Bras Cir. 2012;39:33-40.

20. Jacob D, Raakow R. Single-port versus multi-port cholecystectomy for patients with acute cholecystitis: a retrospective comparative analysis. Hepatobiliary Pancreat Dis Int. 2011;10:521-5.

21. Sawyers JL. Current status of conventional (open) cholecystectomy versus laparoscopic cholecystectomy. Ann Surg. 1996; 223:1-2.

22. Kesteloot K, Penninckx F. The costs and effects of open versus laparoscopic cholecystectomies. Health Economics 1993; 2: 303-312.

23. De Pouvourville G, Ribet-Reinhart N, Fendrick M, Houry S, Testas P, Huguier M. A prospective comparison of costs and morbidity of laparoscopic versus open cholecystectomy. Hepatogastroenterology 1997; 44: 35-9.

24. Ponsky JL. Complications of laparoscopic cholecystectomy. Am J Surg 1991; 161: 393-395.

25. Porte RJ, De Vries BC. Laparoscopic versus open cholecystectomy: A prospective matched-cohort study. HPB Surg. 1996; 9: 71-5.

26. Deziel DJ, Millikan KW, Economou SG, Doolas A, Ko S-T, Airan MC. Complications of laparoscopic cholecystectomy: a national survey of 4,292 hospitals and an analysis of 77,604 cases. Am J Surg. 1993; 165: 9-14.

27. MacFadyen $B V$, Vecchio $R$, Ricardo $A E$, et al. Bile duct injury after laparoscopic cholecystectomy. Surg Endosc. 1998; 12: 315-21.

28. Fullarton GM, Darling K,Williams J, MacDillan R, Bell G. Evaluation of the cost of laparoscopic and open cholecystectomy. Br J Surg. 1994; 81:124-6.

29. Lefering R, Troidl H, Ure BM. Entscheiden die Kosten? Einweg- oder wiederverwendbare Instrumente bei der laparoskopischen Cholecystektomie? Chirurg. 1994; 65:317-25.

30. Sitter H, Lill H, Klotter H-J. Cost analysis for the comparison of a conventional with a minimal invasive surgical procedure. Min Invas Surg. 1992;1:156-7. 